NOTES ON THE DISTRIBUTION OF SOME TRYPETIDAE WITH

\title{
DESCRIPTION OF A NEW SPECIES
}

BY CHARLES W. JOHNSON.

Stenopa vulnerata Loew.

This species has a much greater distribution than has been recorded. I have before me specimens from Cohasset, Mass., August 8 (Owen Bryant); South Kent, Conn., August 21 (A. P. Morse); Mt. Taxoway, N. C. (F. M. Jones); Cranberry, N. C., June 6 (H. W. Wenzel) and Eastern Tennessee (S. N. Rhoads).

Trypeta palposa Loew.

Common on thistle, Cnicus pumilus, at Hyannis Port, Mass., July 4, 1904. Mr. J. A. Cushman also obtained specimens at Woods Hole, July 1, and at Nantucket, July 4, 1905.

Trypeta ruficauda Fabr.

Collected by the writer at Capens, Moosehead Lake, July 21 and on Orr's Island, Maine, July 25, 1907, also taken by Mr. Owen Bryant on Mt. Greylock, Mass., August 8, 1907. I also have specimens from Bolton, N. Y., and Oswego, N. Y., July 27, '97.

\section{ACIURA Nigricornis Doane.}

One specimen was obtained in sweeping at Amsden near Mt. Ascutney, Vermont, July 10, 1908.

Rhagoletis cingulata Loew.

Two specimens, Boston (Dorchester) Mass., June 24 and July 2, 1903 (H. M. Parshley).

Neaspilota aChillez Johnson.

One specimen was obtained on yarrow (Achillea millifolium) at Manomet, Mass., July 27, 1905.

Eurosta fenestrata Snow.

A specimen referable to this species was collected at St. Augustine, Florida.

URELlia ABSTERSA Loew.

One specimen of this widely distributed species was collected at Woods Hole, Mass., July 25, 1903. 
Urellia mevarna Walker (U. solaris Loew).

Another widely distributed obtained on Mt. Greylock, Mass., August 8, '07 (Owen Bryant), Kingston, R. I., Oct. 8, '05 (John Barlow).

EUARESTA PURA Loew.

This species I have thus far seen only from Massachusetts, with the following records :- Bridgewater, June 27, '03; and Nantucket, July 4, '05 (J. A. Cushman); Cohasset, May 29 (Owen Bryant) Auburndale, Aug. 16; Concord, July 18, '04, and Woods Hole, July 25, '03 (C. W. Johnson).

EuAREsta subPura n. sp.

ㅇ Head light yellow, vertex slightly darker than the face, frontal bristles black, occipital bristles yellow; antennae yellow, aristae black, base yellow; eyes dark green or purplish in different lights. Thorax yellow, covered with short light yellow hairs, bristles black; scutellum yellow bearing four black bristles, metanotum brownish covered with a yellowish pollen. Abdomen yellow somewhat shining and covered with procumbent yellow hairs. Marginal bristles of the penultimate segment black, middle of the first and second segments more or less brownish, terminal segment dark brown, ovipositor reddish. Legs yellow with light yellow hairs; halteres light yellow. Wings whitish hyaline, the yellow veins of the basal half giving that portion a yellowish tinge, the markings and reticulations are similar to those of $E$. pura Loew. Length, $5 \mathrm{~mm}$.

Two specimens collected by the writer at Wildwood, N. J., August 12, 1902, in sweeping over sea burweed (Xanthium echinatum). One specimen was also received from Professor John B. Smith, collected at Anglesea, N. J., July 12.

\section{CONVOCATION WEEK MEETINGS IN BOSTON.}

The American Association for the Advancement of Science, and the Affiliated Societies, including the Entomological Society of America and the Association of Economic Entomologists, will meet in Boston during Convocation Week, December 27-31, 1909. Visiting Entomologists will be entertained by the Cambridge Entomological Club at a smoker to be given on some evening during the week. An exhibition, illustrative of recent progress in Entomology, is to be held in connection with these meetings. More detailed announcements will appear in the December number of Psyche. 

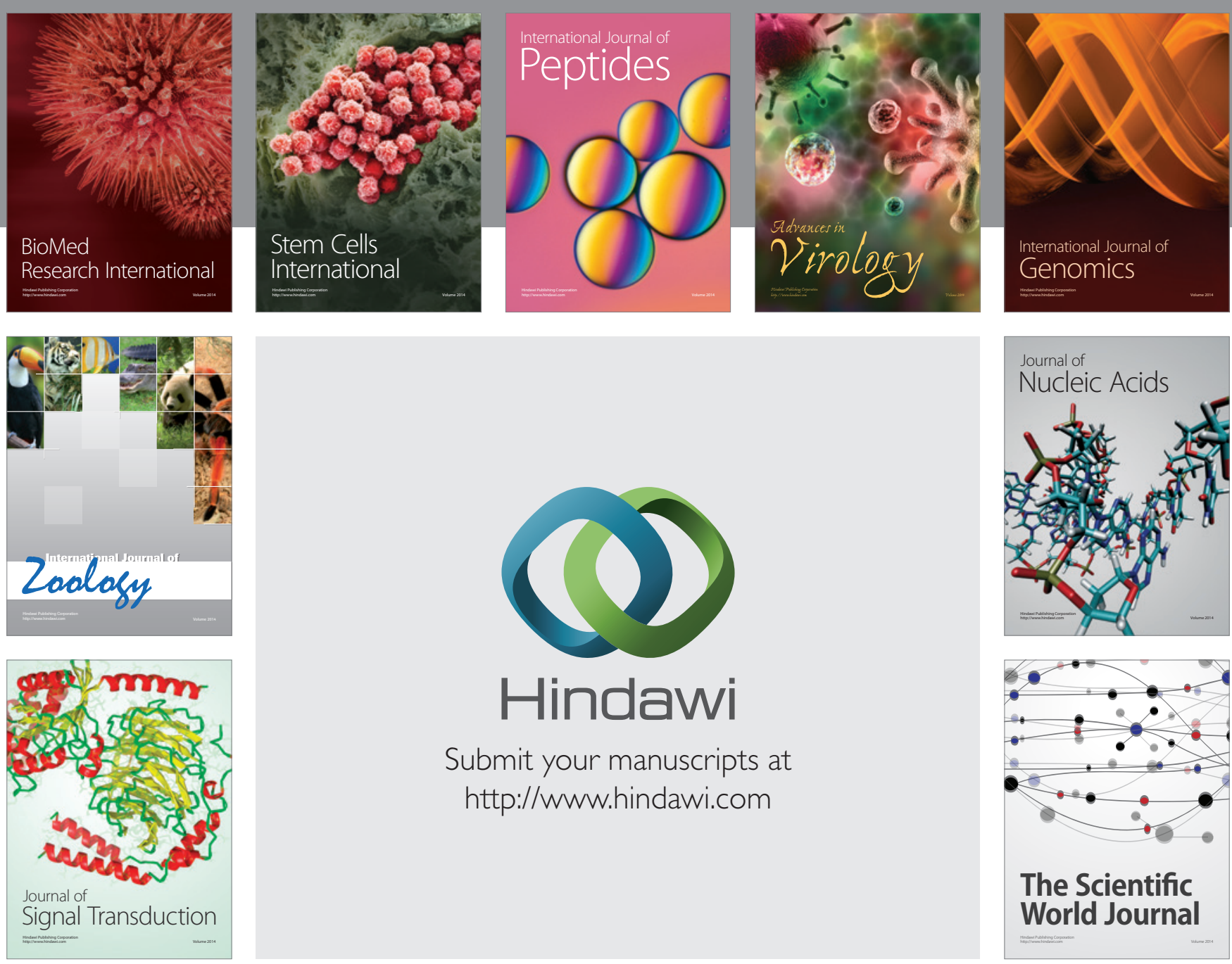

Submit your manuscripts at

http://www.hindawi.com
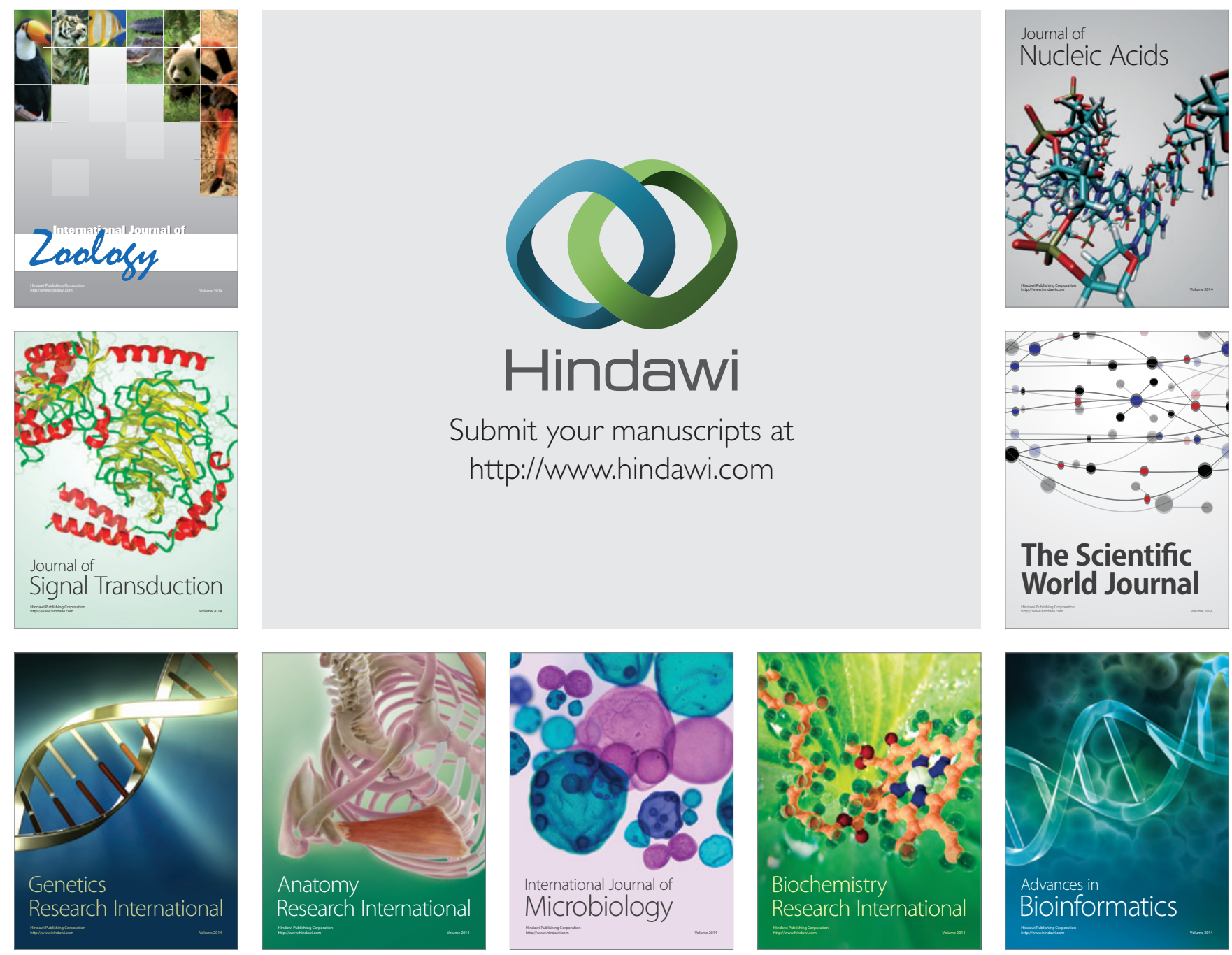

The Scientific World Journal
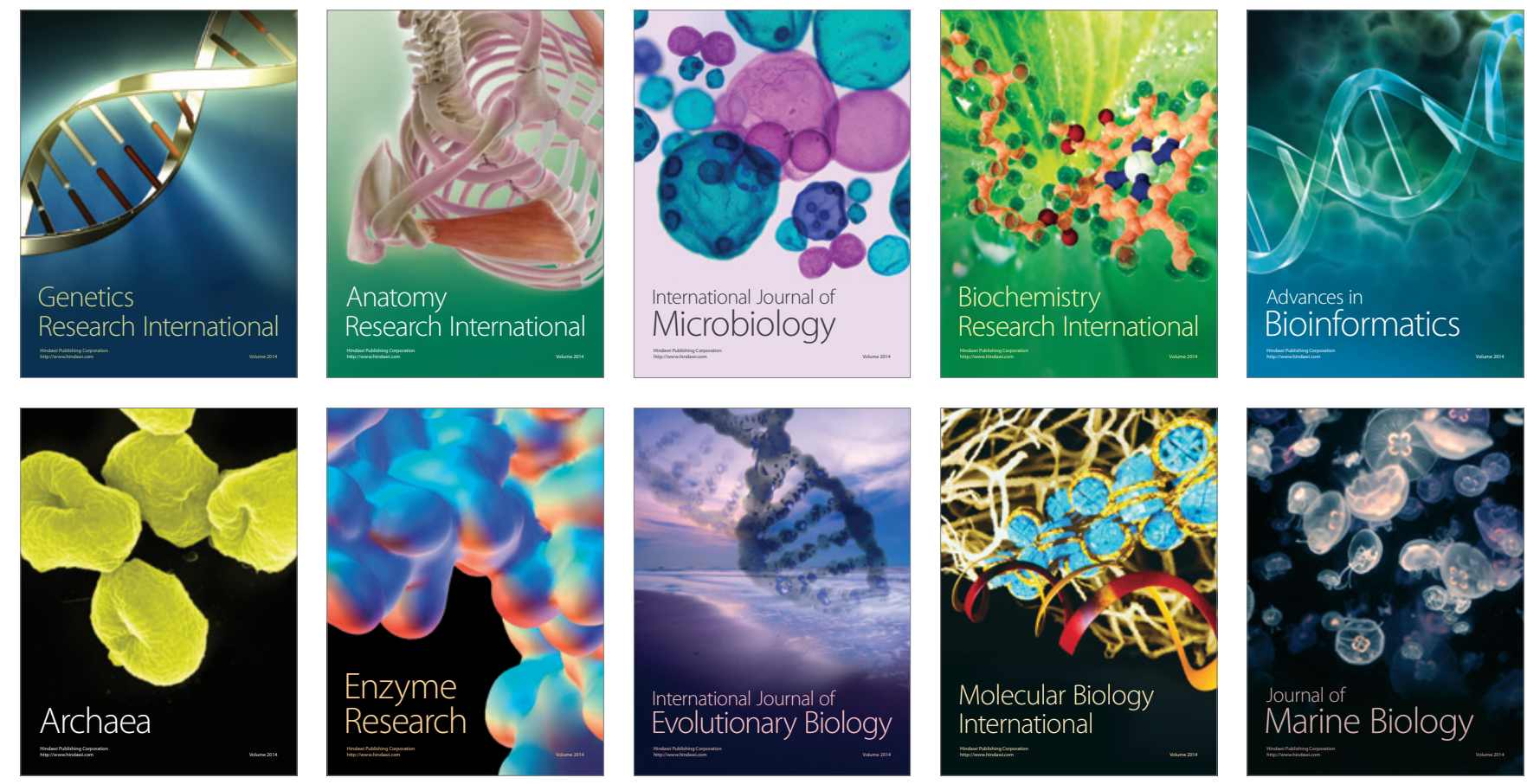